\title{
Influence of the reproductive behavior of Neoneura sylvatica (Odonata: Protoneuridae) on spermatic morphology
}

\begin{abstract}
The present study aimed to verify the behavioral effects on the spermatic morphology of Neoneura sylvatica Hagen in Selys, 1886. For this, males were analyzed behaviorally for intra-sexual competition and for morphology of spermatozoa. With the observation of the five labelled individuals it was possible to observe agonistic relationships between resident males and intruders. When an intruding male attempted to invade the territory of the resident male, there were aggressive contacts. In the reproductive behavior it was possible to observe mating and oviposition with guard after copula in all the couples and attempts of interruption of oviposition by the male intruder. Through the histological analysis individual spermatozoa were observed and not founds in bundles. Spermatozoa dimorphism was found for $N$. sylvatica being the first record for Odonata. This dimorphism is presented as follows: morphotype 1 has a total length of $99 \mu \mathrm{m}$, undifferentiated head of the flagellum, spiral body. Morphotype 2 has a total length of $118 \mu \mathrm{m}$, and it is possible to differentiate the head $(31 \mu \mathrm{m})$ from the flagellum $(86 \mu \mathrm{m})$. The head showed a shape of hook and ripples in the flagellum. We conclude that the behavioral attributes of male intra-sexual competition of $N$. sylvatica can influence the morphological characteristics of spermatozoa generating dimorphism.
\end{abstract}

Keywords: reproduction, heteromorphism, sperm, dragonfly
Volume 5 Issue 3 - 2018

\author{
Millena Vieira Barbosa Neto,' Olávio \\ Campos Júnior,' Gilberto Gonçalves \\ Rodrigues $^{3}$ \\ 'Departamento de Embriologia e Histologia, Universidade \\ Federal de Pernambuco, Brazil \\ ${ }^{2}$ Laboratório Keizi Azami (LIKA), Universidad Federal de \\ Pernambuco, Brazil \\ ${ }^{3}$ Departamento Zoologia, Universidade Federal de Pernambuco, \\ Brazil
}

Correspondence: Millena Vieira Barbosa Neto, Universidade Federal de Pernambuco, Recife, Brazil, Tel (+55)08199895767, Email millenavieiral6@gmail.com

Received: January 30, 2018 | Published: May 18, 2018

\section{Introduction}

In all the species in the animal kingdom, the most specialized cells that are most influenced by reproductive behavior are spermatozoa. For each species the most effective morphological and functional characteristics will be selected, until they become homogeneous throughout the generations. Mating tactics are extremely relevant in defining the morphofunctional attributes of sperm. ${ }^{1}$ The greatest diversity of these cells is found in invertebrates, especially insects. ${ }^{2,3}$ Its rapid and divergent evolution is a generalized pattern that occurs in some groups of insects. An example of the diversification of sperm morphology is sperm polymorphism, in which two or more types of sperm are found in a single male ejaculation. This phenomenon may include variation in the length and structure of the cells. ${ }^{4}$ Some species of Drosophila (Diptera: Drosophilidae) produce nucleated spermatozoa with two different sizes, a type of polymorphism called polyegalia. $^{5}$

Therefore, the present study aimed to verify the behavioral effects on the spermatic morphology of Neoneura sylvatica Hagen in Selys, 1886. The behavioral data of the individuals were observed in preserved areas (Refúgio de Vida Silvestre Matas do Sistema Gurjaú) in the state of Pernambuco, Northeast Brazil.

\section{Results and discussion}

In field the wings of the males were labelled with pento visualize the disputes between them. The work followed the Altman ${ }^{6}$ methodology, called focal observation. The subjects were observed for 60 seconds and the numbers of males and females were quantified. Observations were recorded following the sequence of behaviors of the reproductive process: 1) copulation; 2) tandem (male holding female) and 3) oviposition. For the description of the spermatic morphology, 5 males of the N. sylvatica species were collected and in the laboratory the spermatic ducts and seminal vesicles were removed with the use of tweezers and stereomicroscope. Subsequently, the spermatozoa were mounted on a histological slide, fixed with $4 \%$ paraformaldehyde and stained with Giemsa. The histological observation of the slides and photomicrographs were obtained through the Olympus BX-50 light microscope. Morphometry was done using the Image J Program where the pixels were converted into micrometers.

With the observation of the five labelled individuals it was possible to observe agonistic relations between resident males and intruders. When an intruding male attempted to invade the territory of the resident male, there were aggressive contacts. In the reproductive behavior it was possible to observe copulas and ovipositions, with guard after copula in all the couples and attempts of interruption of oviposition by the male intruder.

Through the histological analysis individual spermatozoa were observed and not in bundles. Sperm dimorphism was found for $N$. sylvatica, being the first record for Odonata. This dimorphism is presented as follows: morphotype 1 has a total length of $99 \mu \mathrm{m}$, undifferentiated head of the flagellum, spiral body. Morphotype 2 has a total length of $118 \mu \mathrm{m}$, and it is possible to differentiate the head $(31 \mu \mathrm{m})$ from the flagellum $(86 \mu \mathrm{m})$. The head showed a shape of hook and ripples in the flagellum (Figure 1).

The maintenance of sperm dysmorphism has explanations already suggested in the literature. One of them is that the anucleated spermatozoa (undifferentiated head of the flagellum) can serve as 
buffers, ${ }^{7-9}$ preventing spermatozoa from other males from reaching the egg. Another explanation would be to provide nutrients to the female. Whereas nucleated spermatozoa (differentiated head of the flagellum) are those that have the function of fecundating the egg. ${ }^{10}$ Therefore, the sperm dimorphism found in $N$. sylvatica may have been a response to intraspecific competition among males, generating high sperm competitiveness and maximizing reproductive success.
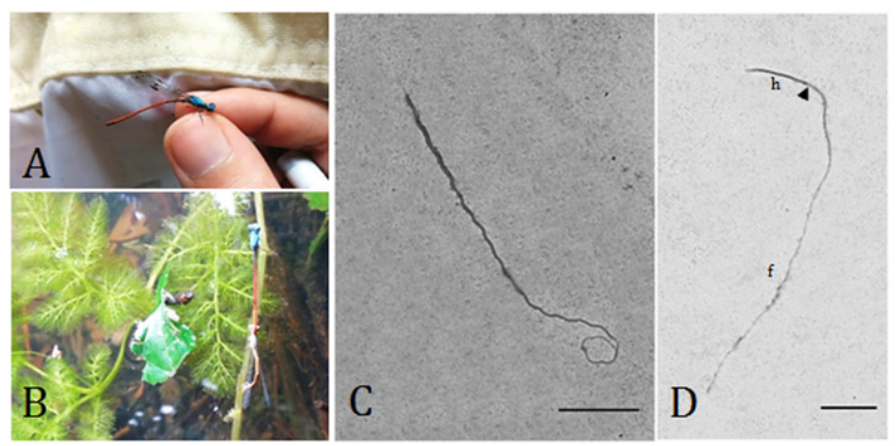

Figure I(A) Labelled male of Neoneura sylvatica. (B) The male holding the female by the pronotum during oviposition. (C) Spermatozoa morphotype I in light microscopy (100x). (D) Spermatozoa Morphotype 2 in light microscopy (I00x). Legends: h- head; f- flagellum; seta-point between the head and flagellum. Bar: I $7 \mu \mathrm{m}$.

\section{Conclusion}

We conclude that the behavioral attributes of intra-sexual competition of Neoneura sylvatica males can influence the morphological characteristics of spermatozoa generating dimorphism.

\section{Acknowledgements}

We thank the Matas Wildlife Refuge of the Gurjaú/CPRH System; to the laboratory Keizi Azami (LIKA) for the provided infrastructure; and Capes/PROPESQ/UFPE for the masters scholarship.

\section{Conflict of interest}

The authors declare no conflict of interest.

\section{References}

1. Oliveira RF, Taborsky M, Brockmann HJ. Alternative reproductive tactics: An integrative approach. New York: Cambridge University Press; 2008:518.

2. Araújo VA, Báo SN, Lino Neto J. Polymorphism of spermatozoa in Largus rufipennis Laporte 1832 (Heteroptera: Pyrrhocoroidea: Largidae). Acta Zoologica. 2012;93(2):239-244.

3. Araújo VA, Lino Neto J, Ramalho FS, et al. Ultrastructure and heteromorphism of spermatozoa in five species of bugs (Hemiptera: Heteroptera). Micron. 2011;42(6):560-567.

4. Swallow JG, Wilkinson GS. The long and short of sperm polymorphisms in insects. Biol Rev Camb Philos Soc. 2002;77(2):153-182.

5. Pasini ME, Redi CA, Cavilglia O, et al. Ultrastructural and cytochemical analysis of sperm dimorphism in Drosophila subobscura. Tissue Cell. 1996;28(2):165-175.

6. Altmann J. Observational study of behavior: sampling methods. Behaviour. 1974;49(3):227-265.

7. Woodward TM. The function of the apyrene spermatozoa of Goniobasis laqueata (Say). J Exp Zool. 1940;85:103-185.

8. Baker RR, Bellis MA. Elaboration of the kamikaze sperm hypothesis: A reply to Harcourt. Anim Behav. 1989;37(5):865-867.

9. Ladle RJ, Foster E. Are giant sperm copulatory plugs? Acta Oecol. 1992;13:635-638.

10. Sivinski J. Sexual selection and insect sperm. Florida Entomol. 1980;63(1):99-111 